会員さまざまシリーズ(7)

\title{
測量とは地球の絵を描くことであり， 光こには量とともに質がある。
}

\author{
一藤森 博美さん*〜 \\ インタビュアー 大我 晴敏**
}

藤森さんの横顔

1923年（大正 12 年）長野県広丘村（現塩尻市）に 生れる。1943年 (昭和 18 年) 東京農業大学卒業後, 中国東北部（旧満州地方）に渡る。1945年復員し農 地開発営団山梨事業所員, 後に山梨県技師。1950 年 (昭和 25 年) 自衛隊の前身である警察予備隊発足時に 測量技術者として入隊。後に防衛庁に名称変更。1964 年 (昭和 42 年) 国際写真測量学会第 5 部会シンポジウ 么準備委員。1 1972 年 (昭和 48 年) 防衛庁を退職。現 在は日本大学講師として農林地質学・測量学を教授し ているとともに, 測量の底辺を作るために越生工業技 術専門学校（埼玉県入間郡越生町）に扔いても教授と しておられる。写真測量学会創立（1962年)より 1965 年 (昭和 51 年) まで理事。1972年 (昭和 48 年) 日本 国際地図学会評議員, 日本古美術協会副会長等を歷任。 著書「農林地質学序説」(立川企業センター) 他多数。 is

藤森さん。写真測量学会発足時の理事として大きな 力を発揮されたこともさることながら，防衛庁という 経歴, そして地図作成の為の写真測量とは異なった分 野で写真測量を活用された研究等で知られている方で す。今回そのあたりを扔話しいただくという主旨で御 登場を願ったのですが，お話しはスケールの大きいこ と!煽られっぱなしで，あっといら間に 2 時間余が過 ぎてしまいました。直線的には写真測量と結びつかな い話が多々ありますが, その心能には全くもって生々 とした写真測量があるのではないかと感じた次第です。 その感じがうまく抢伝えできますが.......

今回のインタビューの所は, 東大生研村井研究室の 談話用応接セット。聴衆数名という T Vで流行ってい る形式（?）で華々しく（?）やりました。

* 越生工業技術専門学校

** 東洋航空事業株式会社

「写真測量とリモートセンシング」Vol 17, №.4，1978

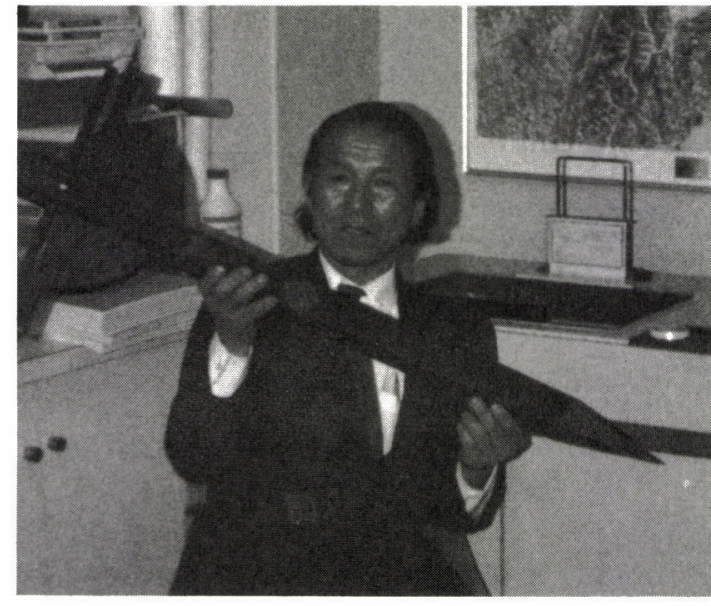

手にもたれているのは, 現在鑑定中のもので 1800 年代 (江戸時代) 伊能忠敬が使用したといわれる測量機材。

色

測量の教師としての括話から……

大我 越生の学校で測量の教育を?

藤森 測量の底辺の教育をやっているところです。内 容は地図編集です。地四というものは，使用する人の 立場に立って作らなければならない。地図で伝える内 容は技術者の自己満足じゃいけない。真実を伝えなけ ればいけない, という考えで教えています。

大我 地図は使う人の立場で……というお話の前提に は今の地図は使う人の立場に立ちきっていない, とい う考えがあるのでしょうか……?

藤森そういうことじゃなくてね。例えば番地を知り たいって人は番地が入っていなければ, いくら精度が 良い地四でも役に立たないでしよう。使う人に目的が あるんだけれども，どういう地図を使うかがわからな くて苦労する。どういう人が, どういう目的あるいは 方面で利用するかで, 地図を適切に選ぶことを基本的 に教えているのです。

大我とすると，目的に対して適当な地図がなければ， それに応じた地図の作り方も教えられてる…… 
藤森 そうです。又あるいは，地図の目的に応じた読 み方-Reading を教えているのです。読み方に関して は，面白い話があるんです。名前を出すわけにいかな いけれど, 有名な一流小説家が $1 / 25,000$ 地形図をみ てある川について記述したんだね。これが「清流云々」 と…, ところが読者が行ってみたら「ドブ川で臭か った」というんだね。(笑い) 地図から, 新興住宅が建 っていて排水がその川に流れ込んでいる，といったこ とを読めなかったんだね。彼のところには文句が来た そうだけれども，もう後の祭り!（大笑）

象

藤森さんの日常生活。 4 時起床。 4 時半まで仕事, 学校までの 2 時間電車の中で仕事の整理（電車は三鷹 から越生まで八高線か池袋経由東上線。2 枚定期を持 っていて，日によってすいていそうな方に乗る）。7 時〜 8 時半講義の準備（頭に全部入れるか黒板に全て 書いてしまう), 手ぶらで講義・実習 (この場合, 藤森 さんは楽しんでやっているのだから学生も楽しまなく ちゃという考えで飽かせない講義となっている), 帰途 電車中で仕事, 自宅で仕事 (計算・実験・観測 etc) 12 時 1 時就寝。

大我疲れませんか。

藤森疲れませんよ。一つのリズムになっているから。 まあ, 一日を 3 倍に働く男というわけで, 労働基準法 違反ですよ。(笑い)

大我 まぎれもなく大変な生活ですが……何か理由が ?

藤森 というのは, 仕事が趣味だからですよ。キャバ レーで夜中の 12 時寸ぎまで飲んでいるのは楽しいし， めったにそれで体をこわすこともないでしょう。それ と同じで, 自分は仕事をしているのが楽しいのですよ。 楽しみで測量学, 地質学をやっているから, 人の 3 倍 やっているんですよ。

大我 そんなに働くのは，損得という基準ではありま せんね。藤森さんにしてみれば，興味あることは面白 いからのめり込んで一生懸命やってしまうということ なのですね。

藤森 昔はキャバレーへ行って飲んだこともあります よ。それと同じことですよ。

大我 基本的姿勢は, 昔も今も変わらない。只興味の 対象が変わったということでしょうか……?

藤森 そう，昔は若かったから女性が対象だったです ね(大笑)，しかし後に夜中に酒を飲んで騒いだエネル
ギーを仕事に使えば……と思ったですね。

大我 悟られたというか……気ゔかれたのは…?

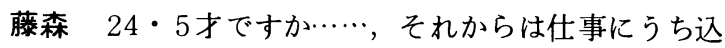
むようになったですね。

负

藤森さんと航空写真の歴史。満州で植生調査をして いるとき「軍機密の写真」を「ほんのチョット」みせ てもらったこと。戦後, 山梨に入っていたとき米国の 4 万を借りたこと。そして, 警察予備隊へ入っに本格 的に。

大我 防衛庁（前身が警察予備隊）に入られたのは。 藤森 測量やる人がいないから, 米軍との接触もある （農地開発営団は GHQの㙉下）からということで引っ ぱられて，予備隊発足の日に入隊したのです。

大我やられた仕事は。

藤森 陸地測量部のものを基礎にしながらも全てアメ リカ式の地図に修正しちゃったのですよ。ひどいもの ですよ。でも, 若かったし, 日本の地図がアメリカ式 でどうなるか, という興味もあって，バー・キャバレー に熱中もしたけれど, 仕事の方も休みなくやりました よ。なにしろ米軍の指揮にあったから食う心配はなく 恵まれてぜいたくなものだったですから……

それから，学校を作って技術者の養成もやったです ね。でも教範がないから全部米軍のものを翻訳してね。 それにしても日本とアメリカでは使い方が違うし，な い言葉があったりで……， スラストラインなんてね。 これが又, 通訳がきて翻訳したものを英語に返すけれ ど意味が通じない。そりゃーそうですわ（笑い）それ に通訳といえば, 川でもカワとガワ, 山でもヤマとサ ンでどう違うかなんて問詰められたりして……(笑) 大我 サンフランシスコ条約後はどのように……

藤森 講和条約後も $2 \cdot 3$ 年は米軍下の惰性だった。 そのうち, 米軍のやり方, 特に物量的に同じ様にやる わけにいかない, 日本独特のやり方で, ということで 地理調査所のやり方でやる方向になったわけ。 大我 その具体的な仕事はどのようなものを。

藤森色々あったけれど，一時期 $1 / 25,000$ 地形図作 成を防衛庁が担当してやりましたね。北海道を主体に。 自分が作業と検査の中心になって。

大我 地理院ではなくて，防衛庁がですか。

藤森 そう防衛庁が計画実施機関として。

大我 秘話ではないでしょうか。はじめてききました。

藤森 防衛庁が数年やって, 色々といきさつはあった 
けれど, 後に地理院へそれらの作業は移管されて, 以 降は，防衛庁としては地理院の版をもらってそれを編 纂・加刷するということになったのです。

$$
\text { 放 }
$$

1966年B・O・A・C機の墜落事故の解明を, 写真 測量の手法を用いて行なう。又日本刀の解析を写真測 量によっておこなう。筆跡の鑑定等と, 特異な研究を されておられます。

大我 色々興味深くやられておりますが, 防衛庁時代 からですか。

藤森 地理院に仕事が移管したので余裕ができた(笑) ということで，研究をはじめたのです。自分は世の中 に真実というものがあり，そこには一方映像というも のがある中で，映像には真実を伝えなければならない， 又真実が伝わるものだ，というところに，このような 解析・鑑定があると考えているのです。

大我 写真についてはどのようにお考えですか。

藤森 写真というのは一つの媒体です。人間が 2 人で 話しているとして，一方の気持ちが他方に伝わるかど うかは, 言語という媒体を通してというわけですね。 写真も同じょうなもので, 刀とか筆跡の鑑定は, その 真実とコミュニケーションするということで，その手 段媒体として写真を使っているのです。

大我 そうすると，写真という媒体を通して真実をみ るためには，広くできることならば深いあらゆる勉強 が必要になりますね。

藤森 そう，例えば刀の場合，手を触れると錆るし傷 むので写真をつかって解析をするのだけれども，何百 冊の本，資料を集めて目を通します。冶金学・地質学・ 燃料学・それらの歴史等々, そうしなければ真実に近 ゔけない。

大我 それを熟すエネルギーはたいへんなものですね。 藤森 いや一, 同じように測量なら測量, 地図なら地 図そのものだけのレベルに停っていては真実とコミュ ニケーションできないですよ。(微)地形学をはじめ大 事なこと，知っておくべきことは数限りなくあります よ。測量でいえば, $\mathrm{X} ・ \mathrm{Y} ・ Z$ だけではない。そこに は量もあるけれど質というものもあるので，その質も 伝えなければならないし，読まなければならないので すよ。
大我 測量というのは, 数字だけで無味乾燥なもの, という感じが支配的だと思いますが，そうではないと いうことですね。

藤森 そうですよ。測量というのは，地球の絵を描い ているといえるもので, たとえ売れなくとも画家が一 生眯命絵を描く精神と同じですよ……

大我 はあ, 藤森さんはそう簡単に云われますけれど ……袈裟なとは……(笑い)

藤森 そんなことないですよ(笑), 森羅万象を描いて いるんだから……興味をもたないのがおかしい...（笑） この興味は限りない喜び一詩歌・俳句をつくったりお 酒を飲む楽しみと同じですよ（笑）

大我 といらことは, 今の例えは測量ですが, 物事に 興味を持たない，魅力を感じないということは，それ に取組む姿勢が悪い，アプローチの仕方が悪い狭いと いうことなのでしょうか。

藤森 そう，そう，そうです。

$$
\text { 公 }
$$

爆笑したのですが，藤森さんは「教科書にあるよう な事は知ったところで何の意味もない。解釈が必要な のですよ。あらゆる角度から多面的に物事をみること」 と話しされておっしゃられたこと,「東京の夢の島, 今は一大ゴミ埋立地ですね。ところがあれは，大博物 館になりますよ。奈良の正倉院以上ですよ。何百年も すれば…..」

生きた解釈が，これほど鮮明に述べられた話はない でしょう。こうみると世の中興味はつきません。

藤森さん, 地球の歴史 47 億年・人類の歴史 300 万年, それをみれば，アクセクするなんて！ということで, ストレス無し, 病気無し, 好きな事やって, いいもの 食べながら，お金がどんどん入ってくるとの事。かく して，いわく「自分は，125才まで生きるつもり」。

当方のなんて小さいことヨ!きっと希望が多いと想 像するのですが，一度「大講演会」をやってもら括う と考えています。(几談)

「勉強する範囲は無限ですよ,これから写真測量を 媒体にして，あらゆるものを観ていきたい……との お話し, 改めて興味あるお話をうかがう機会がほしい ものです。

(1979.4.12インタビュー) 